\title{
Conductive vancomycin-loaded mesoporous silica polypyrrole-based scaffolds for bone regeneration
}

Zanjanizadeh Ezazi, Nazanin; Shahbazi, Mohammad-Ali; Shatalin, Yuri V.; Nadal, Eloy; Mäkilä, Ermei; Salonen, Jarno; Kemell, Marianna; Correia, Alexandra; Hirvonen, Jouni; Santos, Hélder A.

Published in:

International Journal of Pharmaceutics

Link to article, DOI:

10.1016/j.ijpharm.2017.11.065

Publication date:

2018

Document Version

Peer reviewed version

Link back to DTU Orbit

Citation (APA):

Zanjanizadeh Ezazi, N., Shahbazi, M-A., Shatalin, Y. V., Nadal, E., Mäkilä, E., Salonen, J., Kemell, M., Correia, A., Hirvonen, J., \& Santos, H. A. (2018). Conductive vancomycin-loaded mesoporous silica polypyrrole-based scaffolds for bone regeneration. International Journal of Pharmaceutics, 536(1), 241-250.

https://doi.org/10.1016/j.ijpharm.2017.11.065

\section{General rights}

Copyright and moral rights for the publications made accessible in the public portal are retained by the authors and/or other copyright owners and it is a condition of accessing publications that users recognise and abide by the legal requirements associated with these rights.

- Users may download and print one copy of any publication from the public portal for the purpose of private study or research.

- You may not further distribute the material or use it for any profit-making activity or commercial gain

- You may freely distribute the URL identifying the publication in the public portal 


\section{Accepted Manuscript}

Title: Conductive vancomycin-loaded mesoporous silica polypyrrole-based scaffolds for bone regeneration

Authors: Nazanin Zanjanizadeh Ezazi, Mohammad-Ali Shahbazi, Yuri V. Shatalin, Eloy Nadal, Ermei Mäkilä, Jarno Salonen, Marianna Kemell, Alexandra Correia, Jouni Hirvonen, Hélder A. Santos

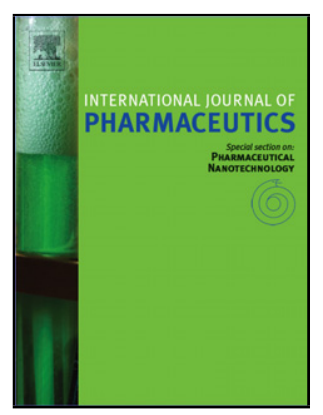

PII:

DOI:

Reference:

S0378-5173(17)31120-1 https://doi.org/10.1016/j.ijpharm.2017.11.065

To appear in: IJP 17185

Received date: International Journal of Pharmaceutics

Revised date: 10-10-2017

Accepted date: 20-11-2017 27-11-2017

Please cite this article as: Ezazi NZ, Shahbazi M-A, Shatalin YV, Nadal E, Mäkilä E, Salonen J, Kemell M, Correia A, Hirvonen J, Santos HA, Conductive vancomycin-loaded mesoporous silica polypyrrole-based scaffolds for bone regeneration, International Journal of Pharmaceutics (2010), https://doi.org/10.1016/j.ijpharm.2017.11.065

This is a PDF file of an unedited manuscript that has been accepted for publication. As a service to our customers we are providing this early version of the manuscript. The manuscript will undergo copyediting, typesetting, and review of the resulting proof before it is published in its final form. Please note that during the production process errors may be discovered which could affect the content, and all legal disclaimers that apply to the journal pertain. 


\title{
Conductive vancomycin-loaded mesoporous silica polypyrrole-based scaffolds for bone regeneration
}

\author{
Nazanin Zanjanizadeh Ezazi ${ }^{1}$, Mohammad-Ali Shahbazi ${ }^{1,2}$, Yuri V. Shatalin ${ }^{3}$, Eloy \\ Nadal $^{1}$, Ermei Mäkilä ${ }^{4}$, Jarno Salonen ${ }^{4}$, Marianna Kemell ${ }^{5}$, Alexandra Correia ${ }^{1}$, Jouni \\ Hirvonen $^{1}$, Hélder A. Santos ${ }^{1,6 *}$
}

${ }^{1}$ Drug Research Program, Division of Pharmaceutical Chemistry and Technology, Faculty of Pharmacy, University of Helsinki, FI-00014 Helsinki, Finland

${ }^{2}$ Department of Micro and Nanotechnology, Technical University of Denmark, 2800 KGs.Lyngby, Denmark

${ }^{3}$ Laboratory of Tissue Engineering, Institute of Theoretical and Experimental Biophysics, Russian Academy of Science, Institutskaya 3, Pushchino, 142290 Moscow Region, Russia

${ }^{4}$ Laboratory of Industrial Physics, Department of Physics and Astronomy, University of Turku, FI-20014 Turku, Finland

${ }^{5}$ Department of Chemistry, University of Helsinki, FI-00014 Helsinki, Finland

${ }^{6}$ Helsinki Institute of Life Sciences (HiLIFE), University of Helsinki, FI-00014 Helsinki, Finland

*Corresponding author:

E-mail: helder.santos@helsinki.fi; Tel.: +358 294159661.

\section{Graphical abstract}




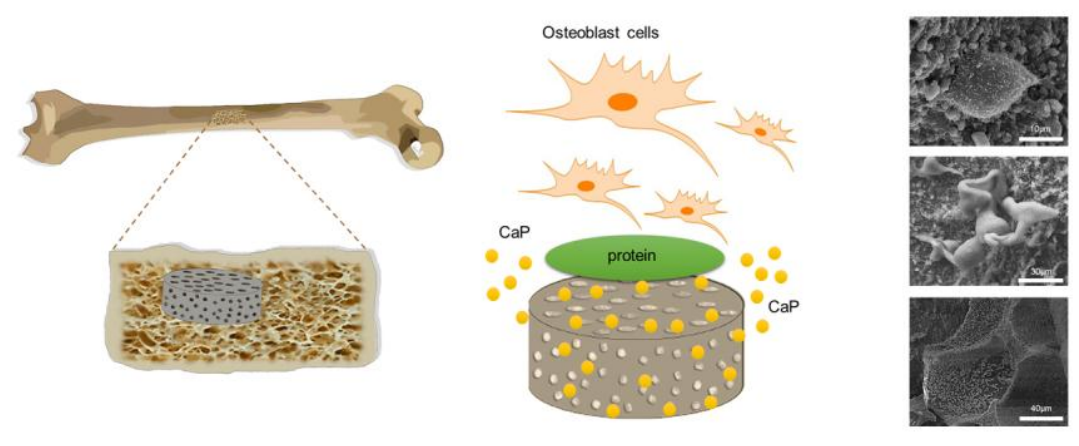

\section{Abstract}

Bone tissue engineering is considered an alternative approach for conventional strategies available to treat bone defects. In this study, we have developed bone scaffolds composed of hydroxyapaptite (HAp), gelatin and mesoporous silica, all recognized as promising materials in bone tissue engineering due to favorable biocompatibility, osteoconductivity and drug delivery potential, respectively. These materials were coupled with conductive polypyrrole (PPy) polymers to create a novel bone scaffold for regenerative medicine. Conductive and non-conductive scaffolds were made by slurry casting method and loaded with a model antibiotic, vancomycin (VCM). Their properties were compared in different experiments in which scaffolds containing PPy showed good mechanical properties, higher protein adsorption and higher percentage of VCM release over a long duration of time compared to non-conductive scaffolds. Osteoblast cells were perfectly immersed into the gelatin matrix and remained viable for 14 days. Overall, new conductive composite bone scaffolds were created and the obtained results strongly verified the applicability of this conductive scaffold in drug delivery, encouraging its further development in tissue engineering applications. 
KEYWORDS: Bone tissue engineering; Conductive polymers; Polypyrrole; Drug delivery; Vancomycin 


\section{Introduction}

Tissue engineering coupled with drug delivery plays a novel key role in the treatment of various diseases through the combination of materials science, biomedical engineering and pharmaceutical sciences (Cui et al., 2010; Hu et al., 2014). Tissue engineering can create a useful ground in which the new tissue can be regenerated in a short period of time with high efficiency. Bone tissue engineering has been extensively studied in recent years in order to overcome the bone defects known as a common clinical problem (ElGhannam, 2005; Zhou et al., 2014). It introduces new approaches to replace the previous methods, such as autografts and allografts, which result in second operation at tissue harvest site, high cost, serious infection and morbidity (Amini et al., 2012). The engineered bone scaffolds are known as an important approach in repairing the structure and physiological function of damaged bone by their porous 3D-structures, which allow regenerating the new bone cells and permit nutrient flow via its interconnections, increasing the chance of treating bone damage (Hollister, 2005). To achieve this goal, it is essential for scaffolds to show suitable osteoconductivity, cell adhesion, degradation, bioactivity and low cytotoxicity (Hu et al., 2014; Ronca et al., 2013). As their main function, scaffolds afford the initial and temporary mechanical stability of the bones and let the cells to proliferate inside the pores to make the new tissue; meanwhile the scaffold gradually starts to degrade and create free space for the new cells (Berthiaume et al., 2011).

Synthetic hydroxyapatite (HAp) is widely used in bone tissue engineering due to its similar chemical composition to the inorganic HAp in bone (Jones R H, 2013). Biocompatibility, osteoconductivity, good chemical bone-bonding ability, as well as supporting and promoting the bone regenerative process make this ceramic an ideal 
component of bone scaffolds (Lewandowska-Lancucka et al., 2015; Rezaei and Mohammadi, 2013). HAp implant systems prevent bacterial pathogens growth (Carlson et al., 2004), while helping to improve osteoblast differentiation. Nevertheless, poor mechanical properties and low degradation rate are the main drawbacks, which demand other materials, such as polymers, other ceramics, or natural phases to be combined to improve the HAp properties (Lewandowska-Lancucka et al., 2015; Rezaei and Mohammadi, 2013).

Silica, for example, with the high potential to induce the mineralization process and improve cell viability, can be a supplement for calcium phosphate $(\mathrm{CaP})$ based systems to facilitate osteoblast cell regeneration (Fwu-Hsing Liu et al., 2011; Heinemann et al., 2011; Lewandowska-Lancucka et al., 2015). In addition, mesoporous silica can be considered as a drug delivery vehicle with controlled release properties, due to presence of silanol groups that facilitate the surface functionalization/coating of the particles (Boccardi et al., 2015; Fussell et al., 2014; Heikkila et al., 2010; Kinnari et al., 2011; Limnell et al., 2011a; Limnell et al., 2011b; Zhang et al., 2013). The promising biocompatibility, thermal and chemical stability, low toxicity, and promoting osteoblast cell activity make mesoporous silica a worthy candidate in bone tissue regeneration purposes (Shadjou and Hasanzadeh, 2015).

Another candidate in bone tissue engineering is gelatin, which has been mostly studied and is widely incorporated with CaP compositions (Bigi et al., 2004). Gelatin is known as a natural biodegradable polymer with high water solubility and biocompatibility, which is able to increase the pore size and improve the workability and mechanical properties of the bone cement (Bigi et al., 2004; Shie et al., 2008). In general, natural bone 
microstructure can be mimicked by a remarkable surface area and interfacial interaction between HAp and gelatin (Chiu et al., 2015).

In biomaterials science, materials with specific properties are used in order to present smart behavior in regeneration treatment. For example, polypyrrole (PPy), is a conductive polymer which is mostly used in smart biomedical composites together with other biomaterials, such as alginate, especially where the conductivity is a major interest of the scaffold properties to stimulate the cell proliferation (Sajesh et al., 2013). PPy has a good electrical conductivity, which is due to p-type conduction, the electrons inter-chain hopping and the anions or cations motion (Balint et al., 2014). It has electric and thermal stability, while it suffers from brittleness, poor mechanical and non-biodegradable properties (Sajesh et al., 2013; Yu et al., 2013). However, incorporating PPy with other materials can be a strategy to overcome these drawbacks. It has been shown that the PPy based composite bone scaffolds can be a new generation of scaffolds with high potency to create $\mathrm{CaP}$ on their surface (Jiang et al., 2005).

There are studies suggesting a desirable differentiation of the cells in the presence of gelatin and HAp, with high alkaline phosphatase (ALP) and osteocalcin activity, and suitable ability to carry and release different drugs (Kim et al., 2005; Liu et al., 2009). Also, combination of chitosan, gelatin and $\mathrm{SiO}_{2}$ with fibrin coating or alginate and $\mathrm{HAp}$, has already been shown acceptable mechanical properties, cell viability, and drug delivery properties (Kavya et al., 2013; Yan et al., 2016). Nevertheless, novel combination of conductive polymers with drug delivery properties is still missing in the previous studies. In addition, in many studies, mechanical strength of the scaffolds is not in the cancellous bone range, which has a compressive strength of 2-12 MPa and Young's 
modulus $(E)$ of $0.05-0.5 \mathrm{GPa}$ (Nicoll, 2011), and they only can be used for short term drug delivery.

In this study, we created a new class of composite bone scaffolds for prolonged drug delivery, by employing PPy (conductive polymer), gelatin (with remarkable ability to induce cell attachment), HAp (as the inorganic component of the bone) and vancomycin (VCM; antibiotic drug)-loaded mesoporous silica microparticles (for anti-infection effect). This way we hypothesize that the chosen materials may enhance the properties of each other and create a novel conductive scaffold to accelerate bone regeneration and simultaneously releasing the antibiotic for prolonged release, which excitingly pave new ways for the applications and further translation in future clinic setups.

\section{Materials and methods}

\subsection{Materials}

Gelatin, HAp, PPy and glutaraldehyde solution $\left(25\right.$ wt.- $\%$ in $\mathrm{H}_{2} \mathrm{O}$ ) were purchased from Sigma-Aldrich. Mesoporous silica $\left(\right.$ SYLOID $^{\circledR} 244$ FP) was kindly provided by Grace Davison, and vancomycin hydrochloride (VCM) was obtained from BioChemica Inc. The chemicals $\mathrm{NaCl}, \mathrm{KCl}, \mathrm{NaHCO}_{3}, \mathrm{NaSO}_{4}$, Tris-buffer, glycerophosphate, ascorbic acid, dexamethasone, sodium dodecyl sulfate (SDS), dimethylsulfoxide (DMSO), 4-(2hydroxyethyl)-1-piperazineethanesulfonic acid (HEPES) were purchased from SigmaAldrich; $\mathrm{K}_{2} \mathrm{HPO}_{4} \cdot 3 \mathrm{H}_{2} \mathrm{O}$ and $\mathrm{CaCl}_{2}$ were purchased from Merck Millipore. $\mathrm{MgCl}_{2} \cdot 6 \mathrm{H}_{2} \mathrm{O}$ and $\mathrm{HCl} 1 \mathrm{M}$ were obtained from Riedel-de Haën and VWR, respectively. Phosphate buffered saline (PBS) 10x, fetal bovine serum (FBS), Dulbecco's Modified Eagle Medium (DMEM), L-glutamine, non-essential amino acids (NEAA) and penicillin streptomycin were purchased from HyClone, USA. Hank's Buffered Salt Solution 
(HBSS) 10x was obtained from Gibco Life Technologies, CellTiter-Glo reagent was purchased from Promega Corporation, USA and the Micro-BCA protein assay kit was obtained from Thermo Fisher Scientific.

\subsection{Preparation of conductive composite scaffold}

Scaffolds were made by solvent casting method on ice (Shahini et al., 2014). In brief, samples were fabricated by adding a mixture of highly viscose HAp and mesoporous silica $(10 \% \mathrm{w} / \mathrm{v}$, each) water-base suspension into $2 \mathrm{ml}$ of melted gelatin solution (1 $\mathrm{g} / \mathrm{mL})$ and warmed in a water bath at $60{ }^{\circ} \mathrm{C}$. PPy $(0.26 \% \mathrm{w} / \mathrm{v})$ was dispersed in water, sonicated and then added to the HAp-mesoporous silica-gelatin mixture. The suspension was then vortexed vigorously to obtain a homogenous slurry. Next, the slurry was casted into 24-well plates on an icebox under shaking conditions, followed by immediate freezing to $-20{ }^{\circ} \mathrm{C}$. Samples were freeze-dried by Heto LyoPro 3000 (Heto-Holten A/S, Denmark) at $-50^{\circ} \mathrm{C}$ for $48 \mathrm{~h}$ to remove the water and create a porous scaffold. Later, the obtained scaffolds were crosslinked by $8 \%$ glutaraldehyde in water for $3 \mathrm{~h}$ to attach the components (HAp, silica and polyppyrrole) on gelatin matrix. Finally, the obtained scaffolds were washed with water and ethanol and freeze-dried for $6 \mathrm{~h}$ (Figure 1A). Two sets of scaffolds were made with this procedure: samples with $\mathrm{PPy}(+\mathrm{P})$ and their counterparts without PPy (-P).

\subsection{Scaffold properties}

The scaffold's cross-section morphology was examined by scanning electron microscopy (SEM; FEI Quanta FEG250). The specific surface area of the scaffolds was evaluated with the Brunauer-Emmett-Teller (BET) method using nitrogen sorption at $-196{ }^{\circ} \mathrm{C}$ 
(TriStar 3000, Micromeritics Inc.) (Zhang et al., 2013). In addition, the porosity was also determined by liquid replacement method. For this, cuboid scaffolds (50-125 mg) were immersed in ethanol (20 mL/sample) and degassed by reducing the pressure within a vacuum chamber to allow the ethanol to run through the pores of the scaffolds for 15-20 min, until no air bubbles could be observed. Finally, the sample weight as immersed was recorded. The porosity of scaffolds was calculated by considering the volume of the pores $\left(\mathrm{V}_{\text {pores }}\right)$ and volume of cuboid scaffolds ( $\left.\mathrm{V}_{\text {scaffold }}\right)$, following Eqs. 1 and 2 (Shahini et al., 2014):

$\mathrm{V}_{\text {pores }}=\mathrm{m}_{1}-\mathrm{m}_{0} / \rho_{\mathrm{EtOH}}$

Porosity $=\left(\mathrm{V}_{\text {pores }} / \mathrm{V}_{\text {scaffold }}\right) \times 100$

where, $m_{0}$ is the dry weight and $m_{1}$ is the weight of the samples after the immersion in ethanol, while the $\rho_{\text {EtOH }}$ is the density of the ethanol.

\subsection{Physicochemical characterization}

The scaffolds were ball-milled by Pulverisette 7 (Fritsch) at $19 g$ for $10 \mathrm{~min}$ with zirconia balls (diameter: 10mm), in dry condition, to obtain a fine powder of each type of samples. Simultaneous thermogravimetric and differential scanning calorimetry (TG/DSC) measurements were done with STA 6000 (PerkinElmer) under a $60 \mathrm{ml} / \mathrm{min}$ flow of synthetic air using a temperature ramp of $20^{\circ} \mathrm{C} / \mathrm{min}$. The chemical structure of the scaffolds was studied with Fourier transform infrared (FTIR) spectroscopy, using a Vertex 70 spectrometer (Bruker Optics) equipped with a MIRacle horizontal attenuated total reflectance accessory (Pike Technologies Inc.). The scans were done using a resolution of $4 \mathrm{~cm}^{-1}$. 


\subsection{Mechanical properties}

Mechanical properties of samples were measured and analyzed with a Lloyd LRX (Lloyd Instruments) at room temperature. New set of samples were made in a $2.5 \mathrm{~mL}$ syringe as a mold to obtain a cylindrical shape scaffold. They were lyophilized for $48 \mathrm{~h}$ at $-50{ }^{\circ} \mathrm{C}$ and then were cut to $6 \mathrm{~mm}$ in diameter and $12 \mathrm{~mm}$ in length. The components were crosslinked together by $8 \%$ glutaraldehyde in water and freeze-dried for $6 \mathrm{~h}$ at $-50{ }^{\circ} \mathrm{C}$. The strength of the samples were tested under vertical force at the cross-section of cylinders with $1.5 \mathrm{~mm} / \mathrm{min}$ speed and $1000 \mathrm{~N}$ maximum load, until they fractured. The compression strength and elastic modulus of three samples of both types were calculated from stress-strain curve plotted by the obtained data from the device (Arifvianto et al., 2017).

\subsection{Swelling ratio measurements}

Swelling ratio was evaluated in order to examine the water absorption in two different types of scaffolds in aqueous solution. In addition, the influence of PPy in swelling ratio was studied. The samples were immersed in $1 \times \mathrm{PBS}(\mathrm{pH}=7)$ at $37{ }^{\circ} \mathrm{C}$ for 7 days (Sajesh et al., 2013) . On each time point (day 1, 4 and 7), each scaffold was taken out of the buffer, tapped on the filter paper to remove the water on the surface and weighed to obtain the wet weight. The swelling ratio was calculated using Eq. 3 (Sajesh et al., 2013):

Swelling ratio $=\left(\mathrm{m}_{\text {wet }}-\mathrm{m}_{\mathrm{dry}}\right) / \mathrm{m}_{\mathrm{dry}}$

where, the $m_{\text {wet }}$ is the weight of samples after the incubation in $1 \times$ PBS buffer and $m_{d r y}$ is the initial weight before immersing in PBS.

\subsection{Biomineralization}


In vitro acellular biomineralization on the surface of the scaffold's pores was examined by immersing the scaffolds in 5 times saturated simulated body fluid $(\operatorname{SBF}(5))$ solution containing $\mathrm{NaCl}, \mathrm{NaHCO}_{3}, \mathrm{KCl}, \mathrm{K}_{2} \mathrm{HPO}_{4} \cdot 3 \mathrm{H}_{2} \mathrm{O}, \mathrm{MgCl}_{2} \cdot 6 \mathrm{H} 2 \mathrm{O}, \mathrm{HCl} 1 \mathrm{M}, \mathrm{CaCl}, \mathrm{NaSO}_{4}$, and Tris-buffer at $37{ }^{\circ} \mathrm{C}$ for 21 days (Cai et al., 2011). The composition was similar to ions concentration in human plasma and it provides a suitable environment to create apatite crystals in vitro (Saravanan et al., 2013). At each time point, the samples were washed carefully with water and freeze-died. The formation of calcium crystals and their morphology were analyzed with a field emission SEM (Hitachi S-4800, Department of chemistry). The Ca:P ratios were measured using an Oxford INCA 350 energy-dispersive X-ray spectrometer (EDX) connected with the Hitachi S-4800.

\subsection{Protein adsorption measurements}

Protein adsorption is the first phenomena after scaffold implantation, which facilitates the cell attachment. Therefore, scaffolds need an initial amount of proteins on the surface for subsequent cell attachment (Dong et al., 2015). For the protein adsorption study, samples were washed with ethanol for $1 \mathrm{~h}$ under shaking, followed by further washings with PBS. PBS+10\% FBS solution was added to each sample and incubated for 4, 14 and $24 \mathrm{~h}$ at $37^{\circ} \mathrm{C}$. Afterwards, samples were tapped by filter paper and washed again with PBS to eliminate the loosely attached FBS. The adsorbed protein was recovered by $2 \%$ SDS and the quantitative protein adsorption was detected by Micro-BCA protein assay kit (Thermo Scientific), following the protocol provided by the manufacturer (Woo et al., 2007). The different sets of scaffolds were treated with FBS in the same way, washed with water, and the morphology and protein attachment was analyzed with SEM (FEI Quanta FEG250). 


\subsection{Drug loading and release studies}

Mesoporous silica (Syloid ${ }^{\circledR} 244 \mathrm{FP}$ ) microparticles $(1 \mathrm{~g})$ were dispersed in $5 \mathrm{mg} / \mathrm{mL}$ of VCM in water for $3 \mathrm{~h}$ at room temperature. The drug-loaded mesoporous silica suspension was then centrifuged at $4020 \mathrm{~g}$ for $7 \mathrm{~min}$ and the supernatant examined by UVVis spectrophotometer (UV-1600(PC), VWR) to detect unloaded drugs. HAp suspension was added to the drug-loaded microparticles in the same ratio as explained in section 2.2, and thereafter, they were added to the falcon tubes containing melted gelatin followed by adding sonicated PPy and pouring everything in 24-well plates by the slurry casting method (Shahini et al., 2014). Next, samples were freeze-dried for $48 \mathrm{~h}$ in $-50{ }^{\circ} \mathrm{C}$ to remove the solvent, and afterwards, the components were crosslinked on the gelatin matrix with $3 \mathrm{~mL}$ of $8 \%$ glutaraldehyde in water. The scaffolds were then washed carefully10 times ( 9 times in water and 1 time in ethanol) and freeze-dried for $6 \mathrm{~h}$. About $1 \mathrm{ml}$ of the supernatant of each step of washing was examined by UV-Vis spectrophotometer at the wavelength of $229 \mathrm{~nm}$ to check the accumulative release of drug during each washing step. The release of $\mathrm{VCM}$ from the $+\mathrm{P}$ and $-\mathrm{P}$ scaffolds (weight average 1.7 and $1.5 \mathrm{~g}$, respectively) was tested at $37^{\circ} \mathrm{C}$ in $3 \mathrm{~mL}$ of PBS at different time points for 4 months. At each time point, $1 \mathrm{~mL}$ of the medium was taken out of the each sample and an equal volume was replaced to maintain the final release volume constant. The release of VCM was studied using a UV-Vis spectrophotometer at the wavelength of $229 \mathrm{~nm}$ for each sample in quadruplicate.

\subsection{Cell studies}

K7M2WT (ATCC ${ }^{\circledR}$ CRL2836 ${ }^{\mathrm{TM}}$ ) osteoblast cells were purchased from ATCC for the in vitro studies. Cells were cultured in DMEM medium supplemented with $10 \%$ FBS, $1 \%$ 
L-glutamine, 1\% NEAA and 1\% (100x) penicillin streptomycin (purchased all from HyClone). They were kept in incubator (16 BB gas, Heraeus Instruments $\mathrm{GmbH}$ ) in atmosphere of $5 \% \mathrm{CO}_{2}$ and $95 \%$ relative humidity and passages used were between 9 and 20 at confluency of ca. $80 \%$. All the scaffolds used for cell studies were sterilized with ethanol for $1 \mathrm{~h}$ and then treated with UV-radiation for $1.5 \mathrm{~h}$ for each side.

\subsection{Cell viability}

ATP-luminescent was measured by CellTiter-Glo luminescent cell viability assay (Promega Corporation, USA) in order to test the cytotoxicity of scaffold's degradation by extract method for 14 days (Frewin Ch et al., 2016). Prior to the test, scaffolds were immersed in DMEM + 10\% FBS and antibiotics for each time point (5 time points, 4 replications) at $37{ }^{\circ} \mathrm{C}$ in $5 \% \mathrm{CO}_{2}$. Also, the medium (DMEM+10\% FBS) was incubated in the same condition for 14 days as the blank medium. About 35,000 osteoblast K7M2 cells were seeded in fresh DMEM $+10 \%$ FBS in each well in 96-well plate for $24 \mathrm{~h}$. At each time point (day 1, 3, 5, 7 and 14) the medium of each well, containing cells, changed with scaffold's and blank medium and incubated for 48 h. After, each sample (+P. -P and blank medium), and positive control containing fresh DMEM $+10 \%$ FBS and negative control 1\% Triton X-100 were washed with buffered salt solution HBSS-HEPES pH 7.4 and followed by addition of the CellTiter-Glo reagent. The samples were kept in dark on the shaker for 2 min and the lysed cells luminescence were measured by Varioskan Flash plate reader (ThermoFisher) within 15 min (Mori et al., 2014).

\subsection{Cell attachment}


The cell morphology and attachment on each type of samples was tested by SEM. First, the samples were immersed in DMEM $+10 \%$ FBS for $24 \mathrm{~h}$. About 10000 cells were then counted and added to each well in 24-well plates, followed by medium replacement every 2 days. At each time point (day 1, 7, 14 and 21), the samples were taken out of the culture medium, washed with PBS (pH 7.4) three times and fixed by $2.5 \%$ glutaraldehyde in PBS at $37{ }^{\circ} \mathrm{C}$ for $1 \mathrm{~h}$. Post-fixation of the samples was then performed using $0.5 \%$ osmium tetroxide in PBS for 1.5 h. Thereafter, different concentrations of ethanol (50, 70, 96 and $100 \%)$ were used to dehydrate the cells. The samples were then coated with goldpalladium alloy/platinum and analyzed with SEM (FEI Quanta FEG250).

\subsection{Statistical analysis}

The results are expressed as mean \pm standard deviations (S.D.) of at least three independent set of measurements. Statistical analysis was achieved by means of one-way analysis of variance (ANOVA) with the level of significance set at probabilities of $* p<$ $0.05, * * p<0.01, * * * p<0.001$, analyzed with OriginPro8.6 software.

\section{Results and discussion}

\subsection{Physicochemical characterization of the scaffolds}

The cross-section of the composite scaffolds was studied by SEM in order to investigate the structure and morphology of the pores created during the preparation of the scaffolds. As it can be seen in Figure 1B, freeze-drying of the casted scaffold created interconnected macroporous structures, composed of gelatin as the backbone matrix and nano-HAp (blue arrows) and mesoporous silica microparticles (green arrows) embedded on the surface,

which is also demonstrated in detail with EDX studies in Figures S1-S3. The 
characteristics of HAp nanoparticles has been already published by the manufacturer, Sigma-Aldrich. It has a molecular weight of $502.31 \mathrm{~g} / \mathrm{mol}$, particle size of $\leq 200 \mathrm{~nm}$ and specific surface area of $\geq 9.4 \mathrm{~m}^{2} / \mathrm{g}$ (A.G. Osorio et al., 2011). As we reported previously (Kinnari et al., 2011), SYLOID ${ }^{\circledR} 244$ FP have a particle size of $2.5-3.7 \mu \mathrm{m}$, a surface area of $311 \pm 14 \mathrm{~m}^{2} / \mathrm{g}$, a pore volume of $1.42 \pm 0.04 \mathrm{~cm}^{3} / \mathrm{g}$ and an average pore diameter of $19.0 \pm 1.1 \mathrm{~nm}$ (Kinnari et al., 2011). In the $+\mathrm{P}$ scaffolds containing PPy, we can see the web-like PPy (red arrows) in the structure attaching on the matrix. The pore size of the scaffolds was analyzed by Image $\mathrm{J} 1.47 \mathrm{v}$, ranging from 200 to $350 \mu \mathrm{m}$ with average diameter size of $281 \mu \mathrm{m}$. Macrosized pores with HAp particles provide good locations for cell attachment and bone ingrowth (Sharma et al., 2016). The specific surface area and density evaluations showed higher area for the $+\mathrm{P}$ scaffolds $\left(5.5 \pm 0.1 \mathrm{~m}^{2} / \mathrm{g}\right)$ compared to the $-\mathrm{P}$ counterpart $\left(2.7 \pm 0.1 \mathrm{~m}^{2} / \mathrm{g}\right)$, while the densities of the $+\mathrm{P}(0.49 \pm 0.05$ $\left.\mathrm{g} / \mathrm{cm}^{3}\right)$ and $-\mathrm{P}\left(0.48 \pm 0.21 \mathrm{~g} / \mathrm{cm}^{3}\right)$ samples were quite similar. The porosity value of $+\mathrm{P}$ was $86.0 \pm 1.2 \%$ and for $-\mathrm{P}$ was $74.0 \pm 2.1 \%$. The results of the specific surface area and porosity indicate that $+\mathrm{P}$ samples showed larger pores (higher porosity) with more irregular pore walls (larger surface area). Moreover, the web-like fibers of PPy on the structure of the scaffolds are suitable locations for the attachment of molecules, cells or particles.

\subsection{Powder characteristics}

The FTIR spectra obtained from the powdered $+\mathrm{P}$ and $-\mathrm{P}$ scaffolds are shown in Figure 1C. The distinct features of the spectra can be assigned in the presence of HAp and mesoporous silica in the composite, as the strong absorbance bands related to the phosphate groups of HAp were observed at 960, 1030 and $1085 \mathrm{~cm}^{-1}$ (Rehman and 
Bonfield, 1997) superimposed with the silica $v(\mathrm{Si}-\mathrm{O}-\mathrm{Si})$ band at $795 \mathrm{~cm}^{-1}$ and the broad band between 1000-1200 $\mathrm{cm}^{-1}$, indicating $\mathrm{Si}-\mathrm{O}$ stretching (Lippincott et al., 1958). Adjacent band are from the gelatin amide bands around 1640 and $1530 \mathrm{~cm}^{-1}$ with an absorbance band at $1345 \mathrm{~cm}^{-1}$ that can be assigned to $\mathrm{Ca}-\mathrm{COO}$ vibrations, indicating chemical binding between the gelatin and HAp (Azami et al., 2010). There is practically no discernible difference between the spectra of $+\mathrm{P}$ and $-\mathrm{P}$ scaffolds, as the possible PPy related bands are masked by the gelatin bands.

Thermal analysis was performed to study the influence of PPy on thermal properties of the scaffolds (Figure 1D). The results of the TGA and DSC scans are shown in Figure 1D, which show similar behavior of both $+\mathrm{P}$ and $-\mathrm{P}$ scaffolds. The TGA/DSC curves show in both samples an initial weight loss accompanied by an endotherm, due to the drying of the sample. The TGA curves continue by the degradation and burning of the organic components, associated with the respective broad DSC endo- and exotherms for the thermal events. Total mass loss can be observed at $800-900{ }^{\circ} \mathrm{C}$, which is $53.2 \pm 0.5$ $\mathrm{w}-\%$ and $53.6 \pm 0.2 \mathrm{w}-\%$ for $+\mathrm{P}$ and $-\mathrm{P}$, respectively, showing that the addition of PPy does not change the behavior of the scaffold under the temperature ramp.

\subsection{Mechanical properties}

Lloyd instrument was used in order to measure and analyze the $(E)$ of the $+\mathrm{P}$ and $-\mathrm{P}$ scaffolds, by forcing the load (1000 $\mathrm{N}$ maximum) to the base surface area until the scaffolds were broken. Mechanical strength is one of the important factors in bone tissue engineering due to the bone function in human body, and this parameter indicates the force threshold which can be applied on the scaffolds before fracture. $E$ value was calculated from the slope of linear stress-strain curve (Figure 2). Figure 2A shows that 
both scaffolds had quite similar mechanical characteristics. The -P scaffolds showed 8 MPa compression strength and Young's modulus of $0.125 \mathrm{GPa}$, and the $+\mathrm{P}$ scaffolds showed almost the same values of $7 \mathrm{MPa}$ compression strength with Young's modulus of $0.11 \mathrm{GPa}$, which was due to the low mechanical properties of PPy polymer. In addition, +P samples were more porous and less dense, which decreased the compression strength. In general, PPy did not decrease the compression strength of the composite scaffold and the combination of the materials showed a similar behaviour as reported in cancellous bone property (Nicoll, 2011), which is due to the crosslinking function of glutaraldehyde $(8 \%)$ used for the amine-aldehyde reaction and the stability enhancement.

\section{4. $\quad$ Swelling ratio studies}

Swelling ability is an important factor in bone tissue engineering. Scaffolds need to be able to adsorb body fluids and make a proper place for nutrient flow and waste removal (Venkatesan et al., 2012). Therefore, the PBS absorption of the $+\mathrm{P}$ and $-\mathrm{P}$ sample were evaluated at $37^{\circ} \mathrm{C}$ during 7 days (Sajesh et al., 2013). As shown in Figure 2B, after $24 \mathrm{~h}$ of immersion in the buffer, the scaffolds absorbed water more than their initial weight and the swelling ratio increased to higher than $100 \%$. Both samples showed an increase in swelling ratio in 7 days. These results suggest a high hydrophilic behavior of the scaffolds, which is an important property for absorbing water to increase the size of the structure (pores), without changing the morphology. Here, the stability of the scaffold is due to the HAp particles (Im et al., 2012). Swelling can facilitate the migration and infiltration of the cells, as well as the diffusion of the nutrients (Saravanan et al., 2013; Sharma et al., 2016). However, the results also indicate that the scaffold containing PPy in its structure had slightly lower swelling ratio compare to the -P samples, which is 
probably due to the hydrophobicity of this polymer (Sajesh et al., 2013), and also due to the fact that $+\mathrm{P}$ scaffolds have high porosity, thus there is less mass to swell in a constant volume. Silica particles are hydrophilic as a result of the silanol groups on its surface (Kinnari et al., 2011). Also, gelatin as a reversible or thermoplastic polymer, which is hydrophilic, has high tendency to swell in higher temperature, while apatite shows lower water uptake due to HAp ceramic nature, making the structure more stable. The interaction between gelatin and HAp make a bond with appropriate swelling and stability properties at the same time (Bundela and Bajpai, 2008; Sharma et al., 2016).

\subsection{Biomineralization}

$\mathrm{CaP}$ crystals $\left[\mathrm{Ca}_{3}(\mathrm{PO} 4)_{2}\right]$ can facilitate the attachment of the osteoblast cells on the scaffold and trigger their differentiation (Saravanan et al., 2013). In this test, acellular biomineralization capability of scaffolds was carried out in vitro over 21 days in SBF(5).

Scaffolds containing hydroxyapatite provide easy nucleation sites for the formation of new spherical crystals (Saravanan et al., 2013). The very first crystals of $\mathrm{CaP}$ were detected on day 7 in $+\mathrm{P}$ samples, and over time more crystals were observed on the surface of the scaffolds (Figure 3). On days 10 and 14, both samples (+P and $-\mathrm{P})$ were covered by multiple layers of $\mathrm{CaP}$, which was also confirmed by the main peaks of $\mathrm{Ca}$ and $\mathrm{P}$ detected by EDX analysis (Figure 3). Although CaP almost coats the entire surface, there were still some pores visible on the surface of the scaffolds. These non-confluent layers eventually merged and completely covered the surface on day 21 for both types of samples, as shown in Figure 3.

The Ca:P ratio was evaluated also by SEM-EDX, showing values of $1.25-1.4$ for both types of scaffolds, while the control (samples before immersion into SBF(5)) had a Ca:P ratio of 1.7. This range of ratio belongs to different type of $\mathrm{CaP}$ compositions. 
Octocalcium phosphate have $\mathrm{Ca}: \mathrm{P}$ ratio of 1.33 , precipitated hydroxyapatite $\mathrm{Ca}: \mathrm{P}$ ratio is 1.33-1.67 and precipitated amorphous calcium phosphate (ACP) Ca:P ratio is $0.67-1.50$

. The metastable compositions of $\mathrm{Ca}: \mathrm{P}, \mathrm{ACP}$ for example, is an intermediate that can change to the more stable composition of apatite and reach a Ca:P ratio of 1.67 (Habraken et al., 2016; Zhao et al., 2011). As shown in Figure 3, Ca, P and Si were the main peaks in spectrum of control samples for $+\mathrm{P}$ and $-\mathrm{P}$ scaffolds. Compared to $-\mathrm{P}$ scaffolds, the $\mathrm{Si}$ peak decreased for $+\mathrm{P}$ samples in day 7 , while the $\mathrm{Ca}$ and $\mathrm{P}$ peaks increased. These results are in line with our observation in SEM study and confirm the ability of our fabricated conductive scaffold to form apatite in a short time period as compared to the nonconductive scaffold. The Si peak completely disappeared at day 10 as the apatite layer coated the surface of the pores. The formation of $\mathrm{CaP}$ crystals indicates the surface bioactivity of both scaffolds and their ability to absorb $\mathrm{PO}_{4}{ }^{3-}$ and $\mathrm{Ca}^{2+}$ due to the electrical charges of the surface. Moreover, the silanol groups of the mesoporous silica microparticles can attract $\mathrm{Ca}^{2+}$ and create a positive layer on the surface, which can then adsorb $\mathrm{PO}_{4}{ }^{3-}$ and make the apatite to grow (Yazdimamaghani et al., 2015).

\subsection{Protein adsorption}

Protein adsorption is a crucial step that occurs right after the implantation of scaffolds into the biological environment, when the proteins give signals to the cells' integrin and facilitate cell attachment to the scaffolds' surface (Chang and Wang, 2011). FBS adsorption was investigated at three time points during $24 \mathrm{~h}$ by BCA assay (quantitative) and SEM (qualitative) to screen the amount and morphology of the proteins on the surface of the pores. As shown in Figure 4A, $+\mathrm{P}$ samples showed higher protein adsorption capacity $(70 \mu \mathrm{g})$ than -P samples $(50 \mu \mathrm{g})$. This result can also be observed in SEM images in Figure 4B in which bigger protein aggregations are attached on the $+\mathrm{P}$ scaffolds 
matrix, while only protein fibers can be observed on -P samples. This can be due to the rougher surface of $+\mathrm{P}$ samples, which is caused by PPy web-like fibers. In PBS buffer, the adsorption process took place at $\mathrm{pH} 7.4$, which was higher than the isoelectric point of BSA (4.8), the main protein of FBS serum. As a consequence, BSA has a negative charge in the physiologic $\mathrm{pH}$ of the human body. Therefore, it can be absorbed on the positive chains of PPy. Overall, PPy created a high porosity, and therefore, high surface for proteins to be adsorbed, and also created the suitable charges on the pores to attract more proteins (Azioune et al., 2002), which led to higher cell attachment.

\subsection{Drug release}

The release of a model antibiotic drug, VCM, from the conductive and non-conductive scaffolds was measured during 4 months. First, it was observed that the mesoporous silica microparticles were loaded with $6.3 \%$ of the drug. During the fabrication of the scaffolds, where $130 \mu \mathrm{g} / \mathrm{ml}$ of drug was lost during crosslinking process and washing steps. At the end, scaffolds were loaded with $2.019 \pm 0.1 \%(+\mathrm{P})$ and $2.4 \pm 0.15 \%(-\mathrm{P})$ of drug based on scaffolds weight.

The cumulative release of VCM from both $+\mathrm{P}$ and $-\mathrm{P}$ composite scaffolds was studied during 4 months in PBS, as shown in Figure 5. No rapid or significant burst release was observed for both types of scaffolds. After 20 days, the composite scaffolds started to reach to a release plateau until almost $80 \%$ drug release for $+\mathrm{P}$ and $50 \%$ for $-\mathrm{P}$ scaffolds. A higher drug release was observed for the $+\mathrm{P}$ samples, which can be due to higher surface area and porosity that the web-like fibers provides (Luo and Cui, 2009; Schnieders et al., 2011). In addition, VCM is a polycationic antibiotic, which might be detached from the positive charges of PPy chains in the $+\mathrm{P}$ samples (Azioune et al., 2002; Williams and Domen, 1990). As was mentioned in section 3.1, the pore size of the mesoporous silica 
microparticles (SYLOID ${ }^{\circledR} 244$ FP) was measured by the BET method, showing an average pore diameter size of $19 \mathrm{~nm}$. Limnell et al. reported that the microparticles showed faster release of indomethacin compare to MCM-41 silica due to their large pore size (Limnell et al., 2011b). In addition, Figure 1B shows the mesoporous silica microparticles embedded on the gelatin matrix, suggesting that the loaded VCM might be trapped in the gelatin matrix. This also explains why the VCM was not completely released. Overall, these scaffold systems were able to avoid the burst release of VCM and extended the time of the release in PBS buffer due to the important role of the gelatin matrix in controlling the drug release.

\subsection{Cell viability}

Cell viability was tested with ATP luminescence assay for $+\mathrm{P}$ and $-\mathrm{P}$ composite scaffolds, and incubated with blank medium during two weeks to check the biocompatibility of scaffolds. The luminescence of the lysed cells in incubated mediums was measured and compared with luminescence of the lysed cells in fresh medium as a positive control (Figure 6). As shown, the scaffold extracted medium did not affect the osteoblast cell viability during 14 days compared to the blank medium. Although we can see a decline in the cell viability after day 5 , the medium which has been extracted from the incubated scaffolds did not show toxicity and the cells were viable as in the blank medium. This suggests that the degradation of the scaffolds did not hinder the cell proliferation and PPy fibers on the matrix did not have any toxic effect on the biocompatibility of the composite scaffolds. The viability of the cells remained almost same for both types of scaffolds with no significant differences. The results prove the fact that conductive polymer of PPy did not show toxicity in $+\mathrm{P}$ composite scaffold in the vicinity of osteoblast cells 


\subsection{Cell attachment}

Cell morphology was investigated in vitro in normal medium (non-osteogenic) during 21 days. Figure 7 shows the interactions of the osteoblast cells and the scaffolds matrices. In day 1 , cells started to attach on the gelatin matrix and high cell infiltration was observed in day 7 , as the cells were seen inside the matrix instead of being attached on the surface of the scaffolds. As the gelatin tended to swell in the medium, the structure became bigger in size and the cells inclined into the scaffolds. The cell infiltration has also been reported in hydrogel matrices in some studies (Annabi et al., 2009; Ji et al., 2011). The swelling ability of the hydrophilic gelatin assisted the cells to adhere onto the surface of the scaffolds and allowed them to enter inside the scaffolds. Overall, the conductive composite showed good biocompatibility and provided an appropriate environment for the attachment, growth and proliferation of the osteoblast cells.

\section{Conclusion}

We have shown here that the scaffolds composed of PPy, gelatin, HAp and VCM-loaded mesoporous silica microparticles exhibited suitable mechanical properties close to bone ones. These novel scaffolds showed compressive strength close to non-conductive scaffolds without decreasing the Young's modulus. The porosity and high surface area of $+\mathrm{P}$ affected the protein adsorption and prolonged the VCM release over time. Web-like fibers of PPy on the gelatin matrix played an important role in the surface charge, which can affect the release of the drug and adsorption of the proteins. In addition, the conductive composite scaffolds promoted the biomineralization and induced the formation of $\mathrm{CaP}$ crystals faster than the non-conductive composites. The swelling of gelatin allowed the matrix of the scaffold to be expanded in the stimulated body fluid or cell medium, which makes enough space for the cells to attach and infiltrate into the 
gelatin. Osteoblast cells were perfectly immersed in the conductive gelatin matrix and stayed viable for 14 days. Overall, we demonstrated that PPy could be used in bone tissue engineering without any toxic effect on osteoblast cells, while retaining essential properties like mechanical strength and create the conductive structure with a potential to release drugs during 4 months from a conductive bone scaffold.

\section{Acknowledgments}

Dr. Wei Li is acknowledged for his generous technical help and suggestions. Dr. Hélder A. Santos acknowledges financial support from the Academy of Finland (decision no. 252215 and 281300), the University of Helsinki Research Funds, the Biocentrum Helsinki, and the European Research Council under the European Union Seventh Framework Programme (FP/2007-2013, grant no. 310892). The authors thank the Electron Microscopy Unit of the Institute of Biotechnology, University of Helsinki, for providing laboratory facilities and assistance.

\section{References}

A.G. Osorio, M.Dunin-Zupanski, Trommer, R.M., 2011. Materials for Bio-Applications, in: Carlos P. Bergmann, Andrade, M.J.d. (Eds.), Nanostructured Materials for Engineering Applications. Springer Science \& Business Media.

Amini, A.R., Laurencin, C.T., Nukavarapu, S.P., 2012. Bone tissue engineering: recent advances and challenges. Crit Rev Biomed Eng 40, 363-408.

Annabi, N., Mithieux, S.M., Boughton, E.A., Ruys, A.J., Weiss, A.S., Dehghani, F., 2009. Synthesis of highly porous crosslinked elastin hydrogels and their interaction with fibroblasts in vitro. Biomaterials 30 , 4550-4557.

Arifvianto, B., Leeflang, M.A., Zhou, J., 2017. Diametral compression behavior of biomedical titanium scaffolds with open, interconnected pores prepared with the space holder method. J Mech Behav Biomed Mater 68, 144-154.

Azami, M., Rabiee, M., Moztarzadeh, F., 2010. Glutaraldehyde Crosslinked Gelatin/hydroxyapatite Nanocomposite Scaffold, Engineered via Compound Techniques. Polym Compos 31, 2112-2120.

Azioune, A., Chehimi, M.M., Miksa, B., Basinska, T., Slomkowski, S., 2002. Hydrophobic proteinpolypyrrole interactions: The role of van der Waals and Lewis acid-base forces as determined by contact angle measurements. Langmuir 18, 1150-1156. 
Balint, R., Cassidy, N.J., Cartmell, S.H., 2014. Conductive polymers: Towards a smart biomaterial for tissue engineering. Acta Biomater 10, 2341-2353.

Berthiaume, F., Maguire, T.J., Yarmush, M.L., 2011. Tissue Engineering and Regenerative Medicine: History, Progress, and Challenges. Annu Rev Chem Biomol 2, 403-430.

Bigi, A., Bracci, B., Panzavolta, S., 2004. Effect of added gelatin on the properties of calcium phosphate cement. Biomaterials 25, 2893-2899.

Boccardi, E., Philippart, A., Juhasz-Bortuzzo, J.A., Beltran, A.M., Novajra, G., Vitale-Brovarone, C., Spiecker, E., Boccaccini, A.R., 2015. Uniform Surface Modification of 3D Bioglass((R))-Based Scaffolds with Mesoporous Silica Particles (MCM-41) for Enhancing Drug Delivery Capability. Front Bioeng Biotechnol 3, 177.

Bundela, H., Bajpai, A.K., 2008. Designing of hydroxyapatite-gelatin based porous matrix as bone substitute: Correlation with biocompatibility aspects. Express Polym Lett 2, 201-213.

Cai, Q., Xu, Q.Q., Feng, Q.F., Cao, X.Y., Yang, X.P., Deng, X.L., 2011. Biomineralization of electrospun poly(L-lactic acid)/gelatin composite fibrous scaffold by using a supersaturated simulated body fluid with continuous CO2 bubbling. Appl Surf Sci 257, 10109-10118.

Carlson, G.A., Dragoo, J.L., Samimi, B., Bruckner, D.A., Bernard, G.W., Hedrick, M., Benhaim, P., 2004. Bacteriostatic properties of biomatrices against common orthopaedic pathogens. Biochem Bioph Res Co 321, 472-478.

Chang, H.I., Wang, Y., 2011. Cell Responses to Surface and Architecture of Tissue Engineering Scaffolds, Regenerative Medicine and Tissue Engineering - Cells and Biomaterials, pp. 569-588.

Chiu, C.K., Lee, D.J., Chen, H., Chow, L.C., Ko, C.C., 2015. In-situ hybridization of calcium silicate and hydroxyapatite-gelatin nanocomposites enhances physical property and in vitro osteogenesis. J Mater Sci: Mater Med 26, 92.

Cui, W.G., Zhou, Y., Chang, J., 2010. Electrospun nanofibrous materials for tissue engineering and drug delivery. Sci Technol Adv Mat 11, 014108.

Dong, W.J., Hou, L.J., Li, T.T., Gong, Z.Q., Huang, H.D., Wang, G., Chen, X.B., Li, X.Y., 2015. A Dual Role of Graphene Oxide Sheet Deposition on Titanate Nanowire Scaffolds for Osteoimplantation: Mechanical Hardener and Surface Activity Regulator. Sci Rep-Uk 5, 18266.

El-Ghannam, A., 2005. Bone reconstruction: from bioceramics to tissue engineering. Expert Rev Med Devices 2, 87-101.

Frewin Ch, Nezafati M, Noble K, Saddow, S., 2016. Cytotoxicity of 3C-SiC Investigated Through Strict Adherence to ISO 10993, Silicon Carbide Biotechnology: A Biocompatible Semiconductor for Advanced Biomedical Devices and Applications. Elsevier Science, pp. 27-61.

Fussell, A.L., Mah, P.T., Offerhaus, H., Niemi, S.M., Salonen, J., Santos, H.A., Strachan, C., 2014. Coherent anti-Stokes Raman scattering microscopy driving the future of loaded mesoporous silica imaging. Acta Biomater 10, 4870-4877.

Fwu-Hsing Liu, Yung-Kang Shen, Lee, a.J.-L., 2011. Selective Laser Sintering of a Hydroxyapatite-silica Scaffold on Cultured MG63 Osteoblasts in Vitro. Int J Precis Eng Man 13, 439-444.

Habraken, W., Habibovic, P., Epple, M., Bohner, M., 2016. Calcium phosphates in biomedical applications: materials for the future? Mater Today 19, 69-87.

Heikkila, T., Santos, H.A., Kumar, N., Murzin, D.Y., Salonen, J., Laaksonen, T., Peltonen, L., Hirvonen, J., Lehto, V.P., 2010. Cytotoxicity study of ordered mesoporous silica MCM-41 and SBA-15 microparticles on Caco-2 cells. Eur J Pharm Biopharm 74, 483-494.

Heinemann, S., Heinemann, C., Jager, M., Neunzehn, J., Wiesmann, H.P., Hanke, T., 2011. Effect of silica and hydroxyapatite mineralization on the mechanical properties and the biocompatibility of nanocomposite collagen scaffolds. ACS Appl Mater Inter 3, 4323-4331.

Hollister, S.J., 2005. Porous scaffold design for tissue engineering. Nat Mater 4, 518-524.

$\mathrm{Hu}$, Y., Zou, S., Chen, W., Tong, Z., Wang, C., 2014. Mineralization and drug release of hydroxyapatite/poly(l-lactic acid) nanocomposite scaffolds prepared by Pickering emulsion templating. Colloids Surf, B122, 559-565.

Im, O., Li, J., Wang, M., Zhang, L.G., Keidar, M., 2012. Biomimetic three-dimensional nanocrystalline hydroxyapatite and magnetically synthesized single-walled carbon nanotube chitosan nanocomposite for bone regeneration. Int J Nanomed 7, 2087-2099.

Ji, C., Annabi, N., Khademhosseini, A., Dehghani, F., 2011. Fabrication of porous chitosan scaffolds for soft tissue engineering using dense gas CO2. Acta Biomater 7, 1653-1664.

Jiang, Z.Z., Ge, D.T., Shi, W., Zhang, Q.Q., 2005. Apatite/polypyrrole composite prepared by a biomimetic process. Synthetic Met 151, 152-155. 
Jones R H, 2013. Porous bioactive ceramic and glass scaffolds for bone regeneration, An Introduction to bioceramics, Second edition. ed. Imperial College Press, London, pp. 463-483.

Kavya, K.C., Jayakumar, R., Nair, S., Chennazhi, K.P., 2013. Fabrication and characterization of chitosan/gelatin/nSiO(2) composite scaffold for bone tissue engineering. Int J Biol Macromol. 59, 255-263. Kim, H.W., Kim, H.E., Salih, V., 2005. Stimulation of osteoblast responses to biomimetic nanocomposites of gelatin-hydroxyapatite for tissue engineering scaffolds. Biomaterials 26, 5221-5230.

Kinnari, P., Makila, E., Heikkila, T., Salonen, J., Hirvonen, J., Santos, H.A., 2011. Comparison of mesoporous silicon and non-ordered mesoporous silica materials as drug carriers for itraconazole. Int J Pharmaceut 414, 148-156.

Lewandowska-Lancucka, J., Fiejdasz, S., Rodzik, L., Latkiewicz, A., Nowakowska, M., 2015. Novel hybrid materials for preparation of bone tissue engineering scaffolds. J Mater Sci: Mater Med. 26, 231.

Limnell, T., Heikkila, T., Santos, H.A., Sistonen, S., Hellsten, S., Laaksonen, T., Peltonen, L., Kumar, N., Murzin, D.Y., Louhi-Kultanen, M., Salonen, J., Hirvonen, J., Lehto, V.P., 2011a. Physicochemical stability of high indomethacin payload ordered mesoporous silica MCM-41 and SBA-15 microparticles. Int J Pharmaceut 416, 242-251.

Limnell, T., Santos, H.A., Makila, E., Heikkila, T., Salonen, J., Murzin, D.Y., Kumar, N., Laaksonen, T., Peltonen, L., Hirvonen, J., 2011b. Delivery Formulations of Ordered and Nonordered Mesoporous Silica: Comparison of Three Drug Loading Methods. J Pharm Sci-Us 100, 3294-3306.

Lippincott, E.R., Vanvalkenburg, A., Weir, C.E., Bunting, E.N., 1958. Infrared Studies on Polymorphs of Silicon Dioxide and Germanium Dioxide. J Res Nat Bur Stand 61, 61-70.

Liu, Y., Lu, Y., Tian, X.Z., Cui, G., Zhao, Y.M., Yang, Q., Yu, S.L., Xing, G.S., Zhang, B.X., 2009. Segmental bone regeneration using an rhBMP-2-loaded gelatin/nanohydroxyapatite/fibrin scaffold in a rabbit model. Biomaterials 30, 6276-6285.

Luo, X.L., Cui, X.T., 2009. Electrochemically controlled release based on nanoporous conducting polymers. Electrochem Commun 11, 402-404.

Mori, M., Almeida, P.V., Cola, M., Anselmi, G., Makila, E., Correia, A., Salonen, J., Hirvonen, J., Caramella, C., Santos, H.A., 2014. In vitro assessment of biopolymer-modified porous silicon microparticles for wound healing applications. Eur J Pharm Biopharm 88, 635-642.

Nicoll, S.B., 2011. Materials for Bone Graft Substitutes and Osseous Tissue Regeneration, Biomaterials for Tissue Engineering Applications: A Review of the Past and Future Trends, pp. 343-362.

Rehman, I., Bonfield, W., 1997. Characterization of hydroxyapatite and carbonated apatite by photo acoustic FTIR spectroscopy. J Mater Sci: Mater Med. 8, 1-4.

Rezaei, A., Mohammadi, M.R., 2013. In vitro study of hydroxyapatite/polycaprolactone (HA/PCL) nanocomposite synthesized by an in situ sol-gel process. Mater Sci Eng :C 33, 390-396.

Ronca, A., Ambrosio, L., Grijpma, D.W., 2013. Preparation of designed poly(D,L-lactide)/nanosized hydroxyapatite composite structures by stereolithography. Acta Biomater 9, 5989-5996.

Sajesh, K.M., Jayakumar, R., Nair, S.V., Chennazhi, K.P., 2013. Biocompatible conducting chitosan/polypyrrole-alginate composite scaffold for bone tissue engineering. Int J Biol Macromol 62, 465471.

Saravanan, S., Trivedi, M., Moorthi, A., Selvamurugan, N., 2013. Biocomposites Containing Chitosan for Bone Tissue Engineering, Marine Biomaterials: Characterization, Isolation and Applications, pp. 529-540. Schnieders, J., Gbureck, U., Vorndran, E., Schossig, M., Kissel, T., 2011. The effect of porosity on drug release kinetics from vancomycin microsphere/calcium phosphate cement composites. J Biomed Mater Res B Appl Biomater 99, 391-398.

Shadjou, N., Hasanzadeh, M., 2015. Bone tissue engineering using silica-based mesoporous nanobiomaterials:Recent progress. Mater Sci Eng :C 55, 401-409.

Shahini, A., Yazdimamaghani, M., Walker, K.J., Eastman, M.A., Hatami-Marbini, H., Smith, B.J., Ricci, J.L., Madihally, S.V., Vashaee, D., Tayebi, L., 2014. 3D conductive nanocomposite scaffold for bone tissue engineering. Int J Nanomed 9, 167-181.

Sharma, C., Dinda, A.K., Potdar, P.D., Chou, C.F., Mishra, N.C., 2016. Fabrication and characterization of novel nano-biocomposite scaffold of chitosan-gelatin-alginate-hydroxyapatite for bone tissue engineering. Mater Sci Eng C Mater Biol Appl 64, 416-427.

Shie, M.Y., Chen, D.C., Wang, C.Y., Chiang, T.Y., Ding, S.J., 2008. Immersion behavior of gelatincontaining calcium phosphate cement. Acta Biomater 4, 646-655.

Venkatesan, J., Pallela, R., Bhatnagar, I., Kim, S.K., 2012. Chitosan-amylopectin/hydroxyapatite and chitosan-chondroitin sulphate/hydroxyapatite composite scaffolds for bone tissue engineering. Int $\mathbf{J}$ Biol Macromol 51, 1033-1042. 
Williams, L., Domen, R.E., 1990. Zeta-Potential and Vancomycin-Red Blood-Cell Interactions. Arch Pathol Lab Med 114, 1262-1263.

Woo, K.M., Seo, J., Zhang, R., Ma, P.X., 2007. Suppression of apoptosis by enhanced protein adsorption on polymer/hydroxyapatite composite scaffolds. Biomaterials 28, 2622-2630.

Yan, J.X., Miao, Y.T., Tan, H.P., Zhou, T.L., Ling, Z.H., Chen, Y., Xing, X.D., Hu, X.H., 2016. Injectable alginate/hydroxyapatite gel scaffold combined with gelatin microspheres for drug delivery and bone tissue engineering. Mat Sci Eng C-Mater 63, 274-284.

Yazdimamaghani, M., Razavi, M., Mozafari, M., Vashaee, D., Kotturi, H., Tayebi, L., 2015. Biomineralization and biocompatibility studies of bone conductive scaffolds containing poly $(3,4-$ ethylenedioxythiophene): poly(4-styrene sulfonate) (PEDOT:PSS). J Mater Sci-Mater M 26, 274.

Yu, Q., Xu, S., Zhang, K., Shan, Y., 2013. Multi-porous electroactive poly(L-lactic acid)/polypyrrole composite micro/nano fibrous scaffolds promote neurite outgrowth in PC12 cells. Neural Regen Res 8, 3138 .

Zhang, H., Shahbazi, M.A., Makila, E.M., da Silva, T.H., Reis, R.L., Salonen, J.J., Hirvonen, J.T., Santos, H.A., 2013. Diatom silica microparticles for sustained release and permeation enhancement following oral delivery of prednisone and mesalamine. Biomaterials 34, 9210-9219.

Zhao, J., Liu, Y., Sun, W.B., Zhang, H., 2011. Amorphous calcium phosphate and its application in dentistry. Chem Cent J 5, 40.

Zhou, R., Xu, W., Chen, F., Qi, C., Lu, B.Q., Zhang, H., Wu, J., Qian, Q.R., Zhu, Y.J., 2014. Amorphous calcium phosphate nanospheres/polylactide composite coated tantalum scaffold: facile preparation, fast biomineralization and subchondral bone defect repair application. Colloids Surf, B 123, 236-245. 


\section{FIGURE CAPTIONS}

Figure 1. (A) Schematic representation of the procedure to fabricate conductive scaffolds. Slurry casting method followed by freeze-drying for $48 \mathrm{~h}$ and crosslinking with $8 \%$ glutaraldehyde. The samples were washed by distilled water and ethanol to remove the remained glutaraldehyde and then dried by freeze-drying method for $6 \mathrm{~h}$ at $-50^{\circ} \mathrm{C}$. (B) Cross-section SEM images of $+\mathrm{P}$ scaffolds, demonstrating interconnected pores. Arrows in the magnified image show web-like PPy (red) attached to the gelatin matrix on the scaffold. Green arrows are showing mesoporous silica microparticles and blue arrows indicate the HAp. (C) FTIR spectra of ball-milled $+\mathrm{P}$ and $-\mathrm{P}$ scaffolds. Green lines correspond to the stretches of $\mathrm{Si}-\mathrm{O}-\mathrm{Si}$ and $\mathrm{Si}-\mathrm{O}$ bonds responsible for mesoporous silica microparticles, blue line shows the $\mathrm{PO}_{4}$ bending of HAp, and orange line shows the bonds that correspond to gelatin and yellow line of gelatin and HAp Ca-COO bond. (D) TGA/DSC graphs in synthetic air at $20^{\circ} \mathrm{C} / \mathrm{min}$ for $+\mathrm{P}$ and $-\mathrm{P}$ samples. 
Figure 1

A
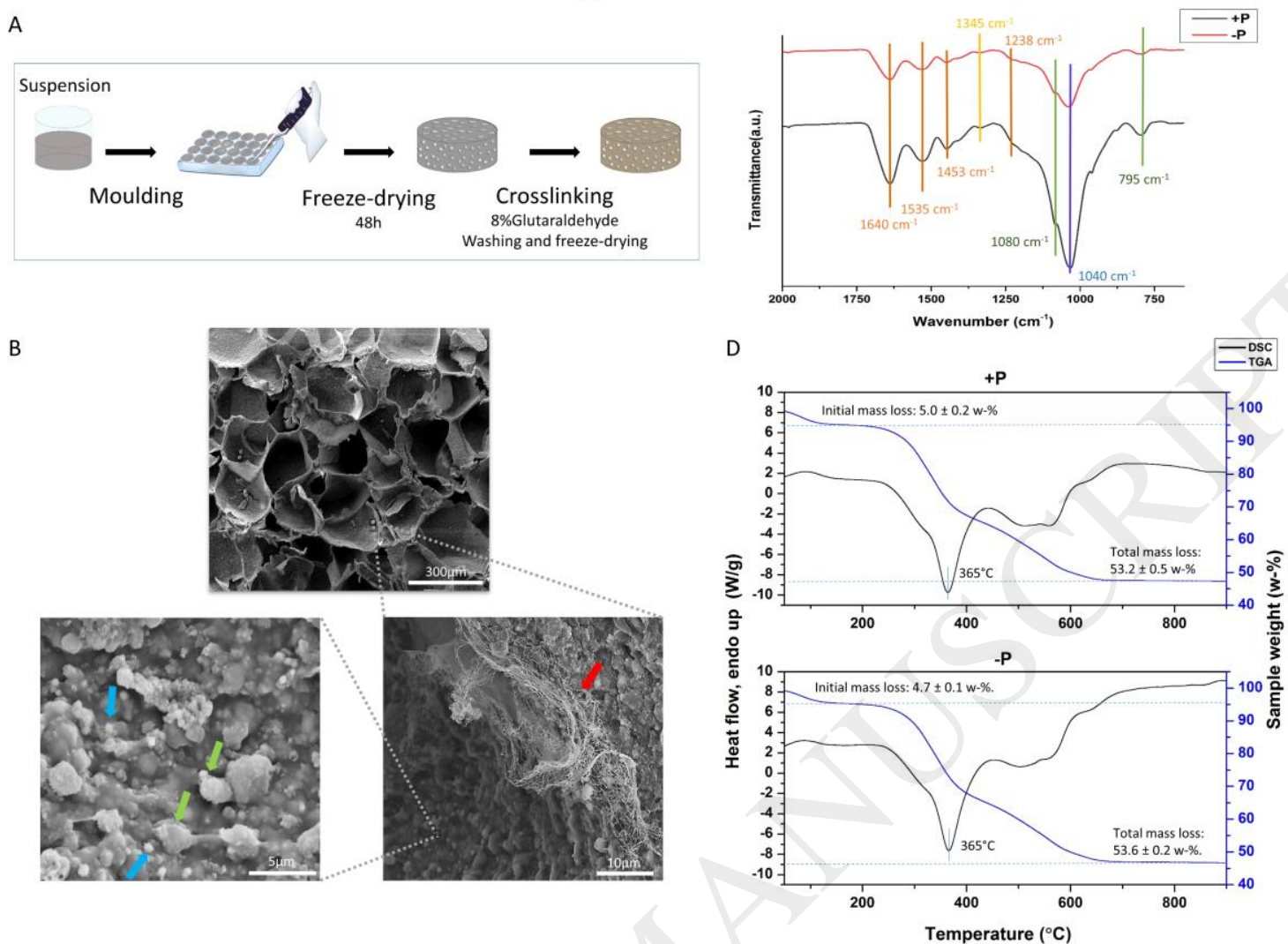

Figure 2. (A) Stress-strain curve of $+\mathrm{P}$ and -P samples. (B) Water adsorption during 7 days with over $100 \%$ of weight increase for $+\mathrm{P}$ and $-\mathrm{P}$ samples. Errors bars represent mean \pm S.D $(n=3)$. Statistical analysis was made by one-way analysis of variance (ANOVA) with the level of significance set at the probability of $* * p<0.01$. 


\section{Figure 2}
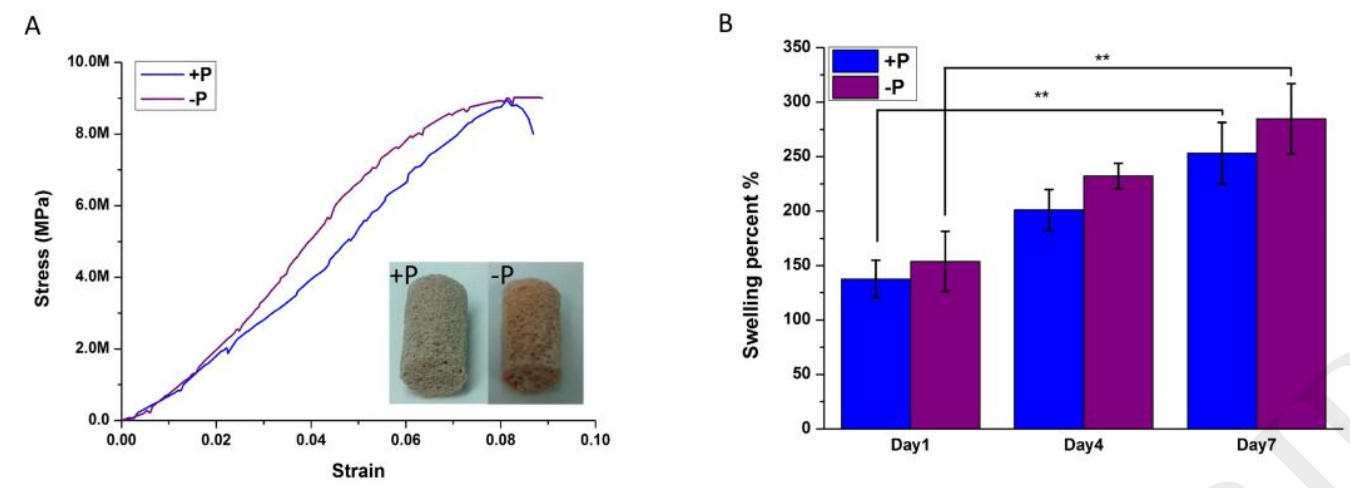

Figure 3. SEM images of $\mathrm{CaP}$ localization on the pores of $+\mathrm{P}$ and $-\mathrm{P}$ samples after 7, 10, 14 and 21 days of immersion in SBF (5). First CaP crystals can be seen on day 7 in $+\mathrm{P}$ samples, while the -P surface showed no crystal formation. After 10 days, samples were covered by non-confluent multilayers of CaP. These layers became confluent over time until day 21, which resulted in multilayered confluent $\mathrm{CaP}$ coating. Scale bares are 20 $\mu \mathrm{m}$. Energy-dispersive X-ray spectroscopy (EDX) on the right side of each SEM image shows the main peaks of $\mathrm{Ca}$ and $\mathrm{P}$. The Si peak disappeared from day 10 onwards due to the whole coverage of $\mathrm{CaP}$ on the pores of the scaffolds. 


\section{Figure 3}

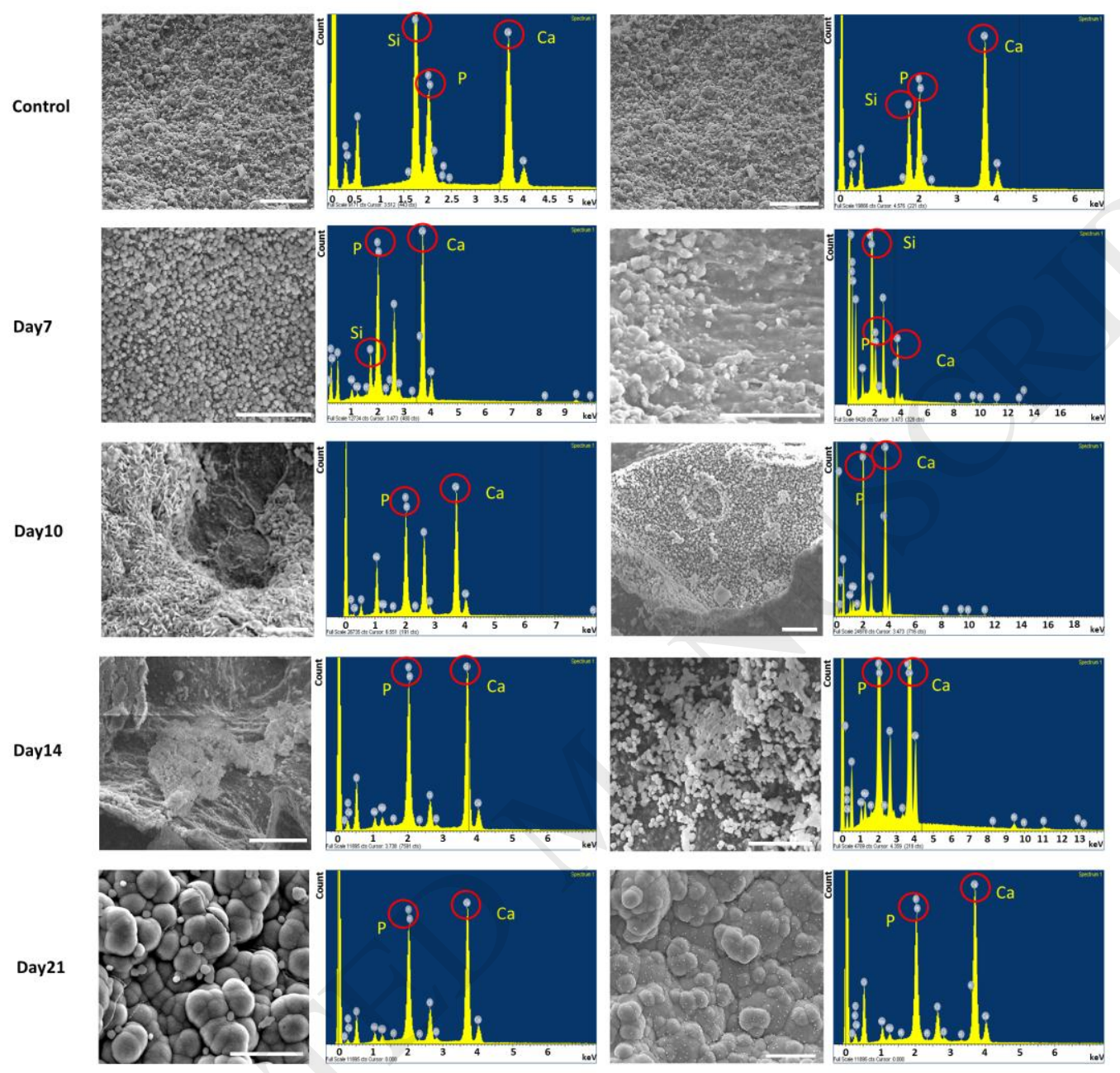

Figure 4. FBS proteins adsorption during 24 h. (A) Quantitative FBS concentration after

4, 14 and 24 h of incubation in PBS+10\% FBS solution at $37{ }^{\circ} \mathrm{C}$. Errors bars represent mean \pm S.D $(n=3)$. Statistical analysis was made by one-way analysis of variance (ANOVA) with the level of significance set at probabilities of ${ }^{*} p<0.05$ and ${ }^{*} p<0.01$.

(B) SEM imaging of scaffolds after 4, 14 and $24 \mathrm{~h}$ of incubation in PBS+10\% FBS 
solution at $37^{\circ} \mathrm{C}$, showing the morphology of the attached proteins on the pores. Scale bars are $50 \mu \mathrm{m}$.

\section{Figure 4}

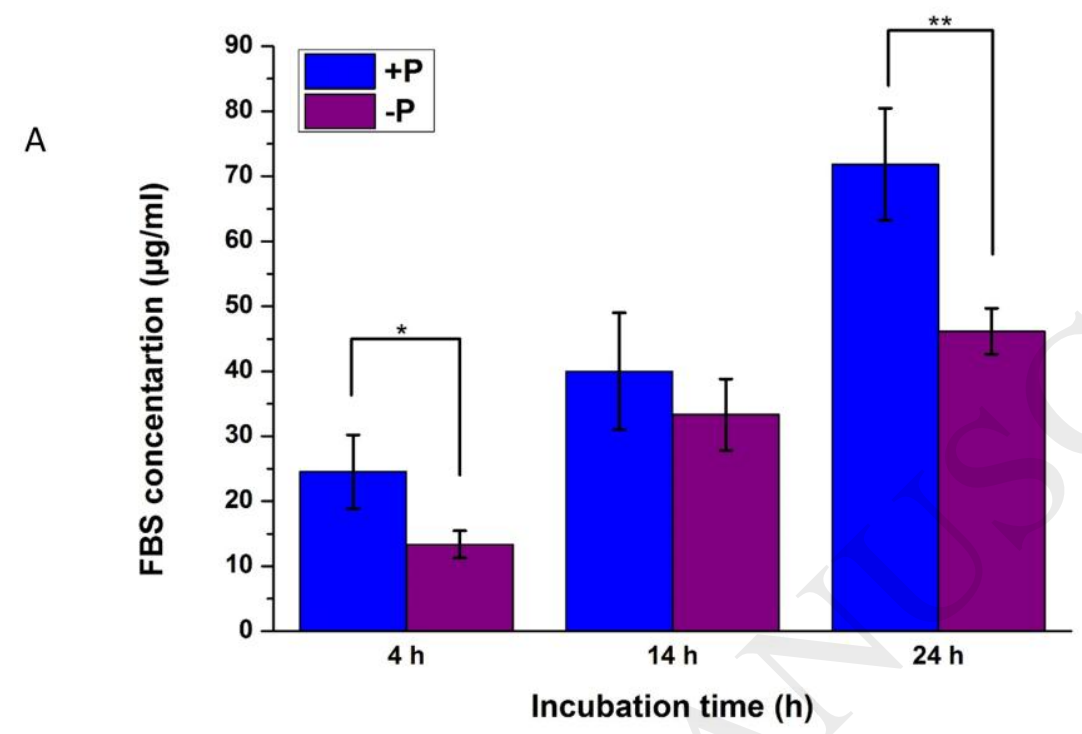

B

$4 \mathrm{~h}$
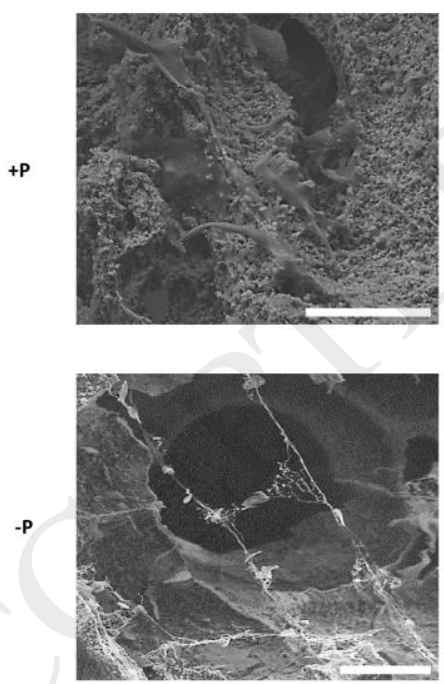

$14 \mathrm{~h}$
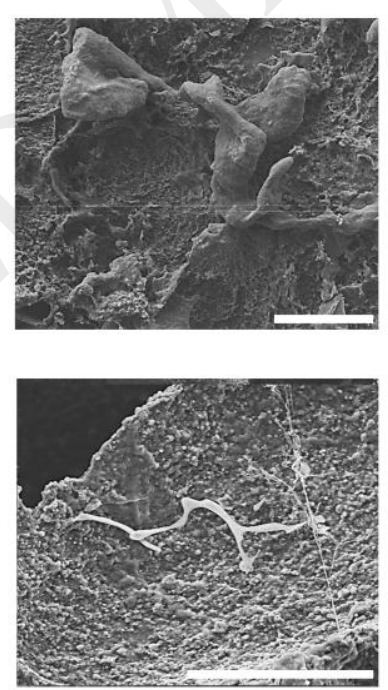

$24 \mathrm{~h}$
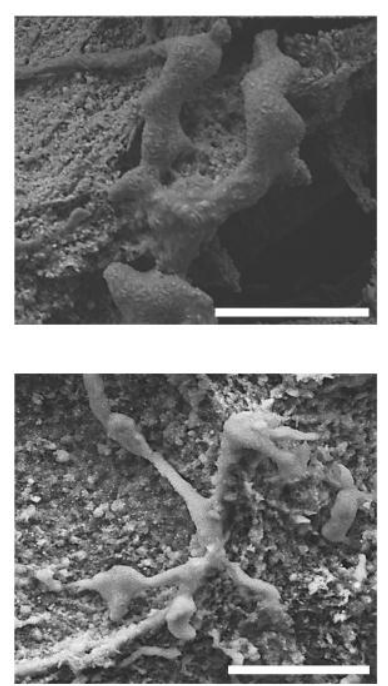

Figure 5. The cumulative release of VCM from $+\mathrm{P}$ and $-\mathrm{P}$ scaffolds $(n=4)$ immersed in PBS pH 7.4 for 4 months at $37{ }^{\circ} \mathrm{C}$. The $+\mathrm{P}$ samples released almost $80 \%$ of VCM, while the maximum release for $-\mathrm{P}$ samples was around $50 \%$. Statistical analysis was made by 
one-way analysis of variance (ANOVA) with the level of significance set at the probability of $* p<0.05$.

\section{Figure 5}

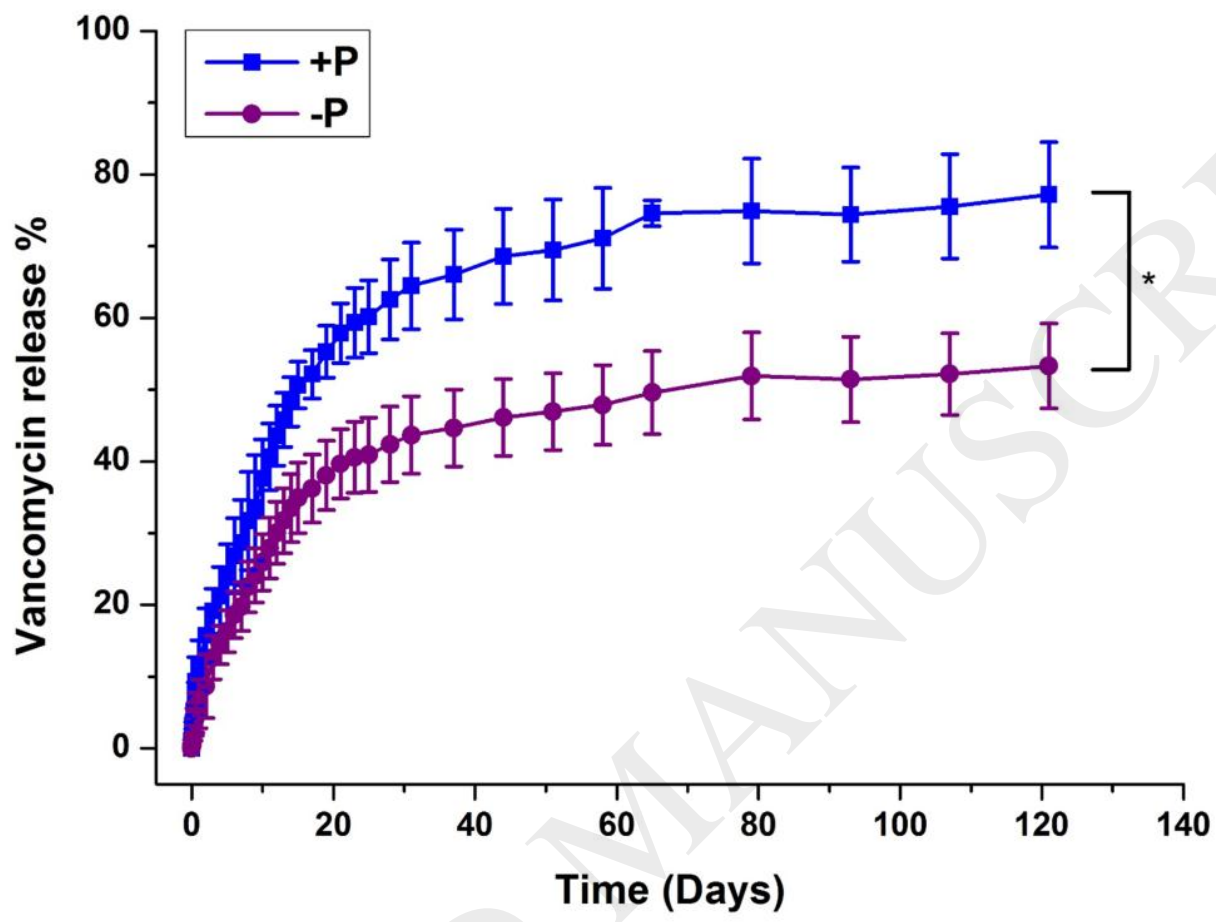

Figure 6. The viability of osteoblast cells in medium extracted from $+\mathrm{P}$ and $-\mathrm{P}$ scaffolds, and incubated with blank medium for two weeks compared with fresh medium (positive control) and Triton X-100 (negative control), which is represented by measuring ATP luminescence. Errors bars represent mean \pm S.D $(n=4)$. Statistical analysis was achieved by means of one-way analysis of variance (ANOVA) with the level of significance set at probabilities of $* p<0.05, * * p<0.01$ and $* * * p<0.001$. 


\section{Figure 6}

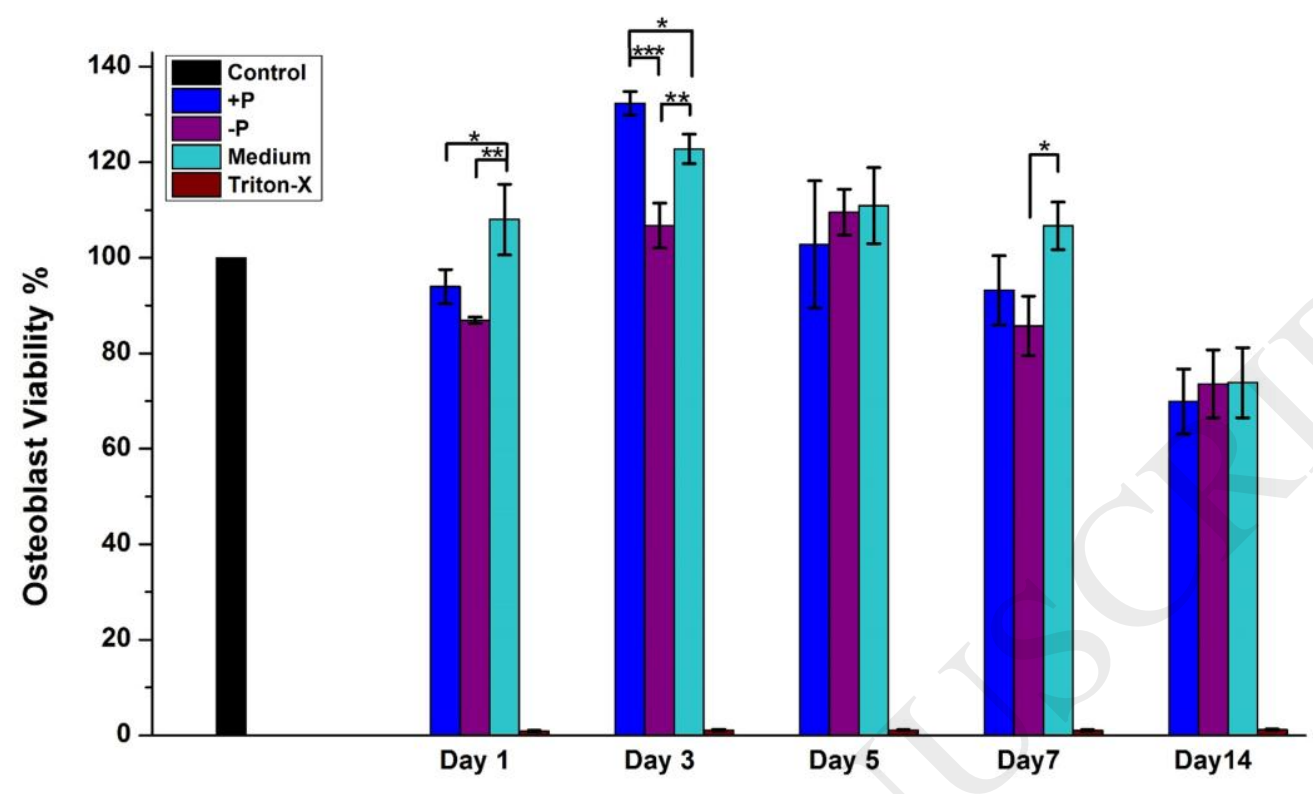

Figure 7. Cell infiltration after 1, 7, 14 and 21 days of immersing the scaffolds $(+\mathrm{P}$ and -P samples) in normal medium with $10 \% \mathrm{FBS}$. The cells on $+\mathrm{P}$ samples in day 7 spread on the matrix with elongated shape. Arrows show the cells that are covered by crystals produced in the medium. Scale bars are $20 \mu \mathrm{m}$. 


\section{Figure 7}

$-P$

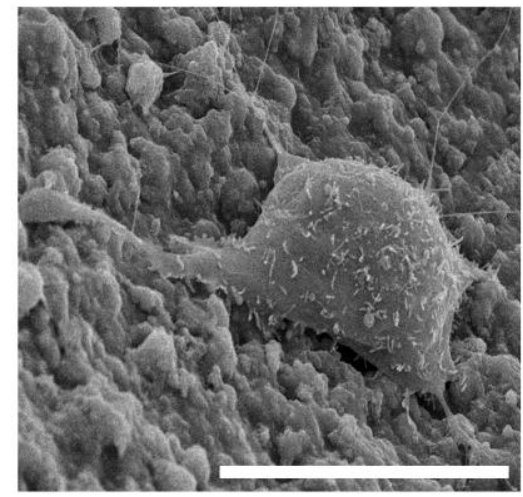

Day 7
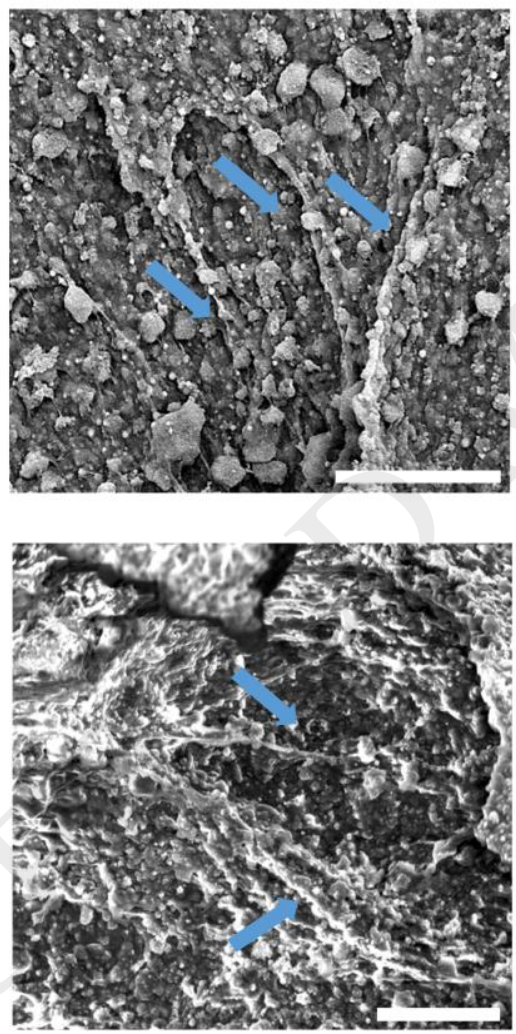

Day 21

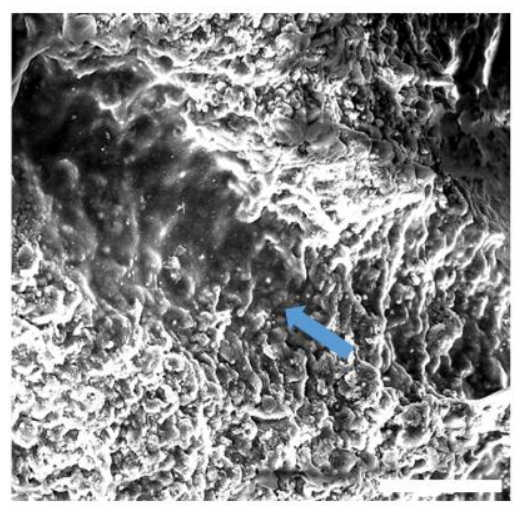

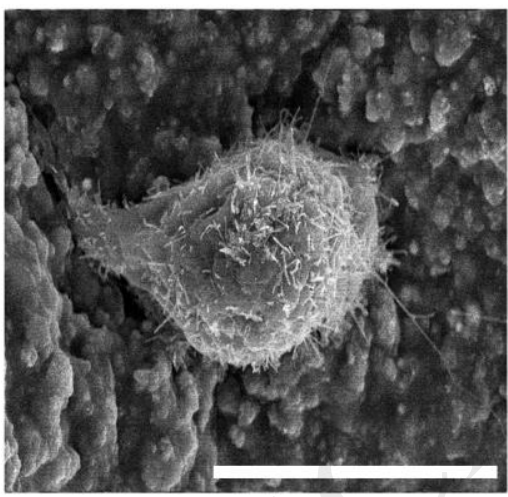
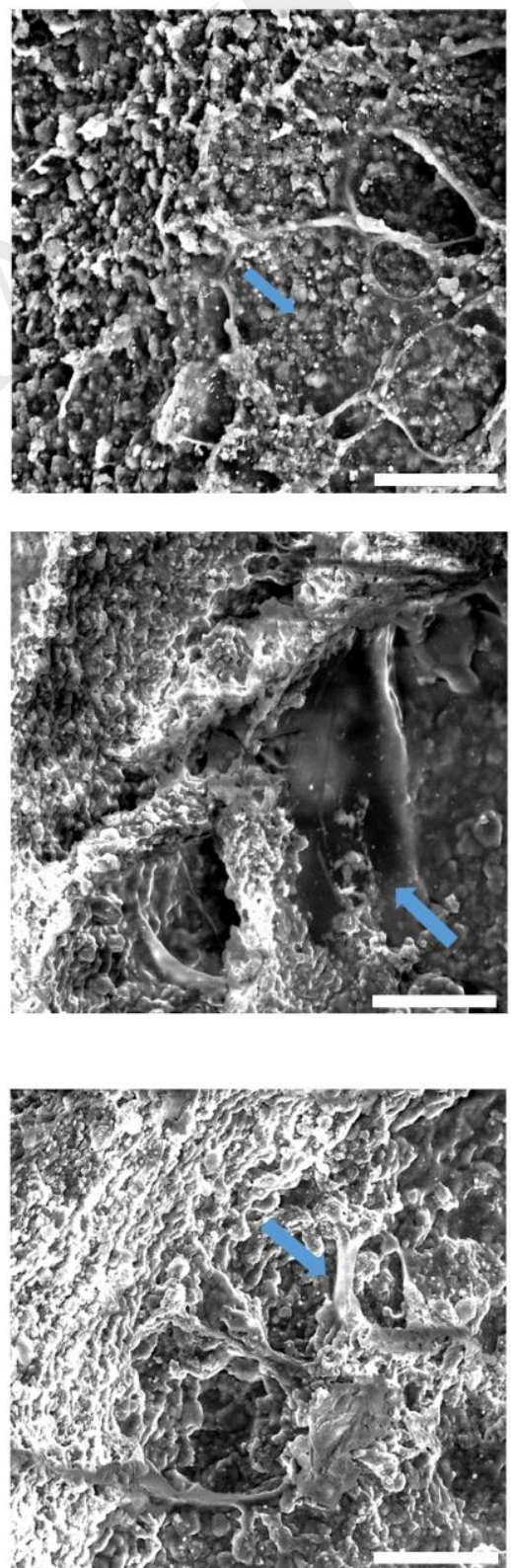